$\begin{array}{ccc}\text { Tersedia online di: http://ejournal-balitbang.kkp.go.id/index.php/jppi } & \text { JURNAL } \\ \text { e-mail:jppi.puslitbangkan@ gmail.com } & \text { PENELITIAN } \\ \text { PERIKANAN } & \text { INDONESIA } \\ \text { JURNAL PENELITIANPERIKANANINDONESIA } & \text { Volume 22 Nomor 4 Desember 2016 } \\ \text { p-ISSN: 0853-5884 } & \text { e-ISSN: 2502-6542 } \\ \text { Nomor Akreditasi: 653/AU3/P2MI-LIPI/07/2015 }\end{array}$

\title{
LAJU TANGKAP, KOMPOSISI, SEBARAN, KEPADATAN STOK DAN BIOMASA UDANG DI LAUT JAWA
}

\section{CATCH RATE, COMPOSITION, DISTRIBUTION, STOCK DENSITY AND BIOMASS OF SHRIMPS IN JAVA SEA}

\author{
Tirtadanu*1 $^{\star 1}$, Suprapto ${ }^{1}$ dan Tri Ernawati ${ }^{1}$ \\ 'Balai Penelitian Perikanan Laut, Jln. Muara Baru Ujung, Komp. Pelabuhan Nizam Zachman, Jakarta Utara 14430. Indonesia \\ Teregistrasi I tanggal: 22 Juli 2016 ; Diterima setelah perbaikan tanggal: 11 Januari 2017 ; \\ Disetujui terbit tanggal: 11 Januari 2016
}

\begin{abstract}
ABSTRAK
Penangkapan udang di Laut Jawa telah dilakukan sejak lama dan aktivitasnya berpengaruh besar terhadap perubahan stok dan ekologi perairan. Data dan informasi terbaru terkait laju tangkap, komposisi, sebaran dan kepadatan stok udang diperlukan sebagai dasar dalam pengelolaan sumberdaya udang yang berkelanjutan di Laut Jawa. Tujuan penelitian adalah untuk mengetahui laju tangkap, komposisi, sebaran dan kepadatan stok udang di Laut Jawa. Penelitian dilakukan pada Oktober dan November 2015 dengan menggunakan armada Kapal Riset Madidihang 02 di Laut Jawa. Kepadatan stok diestimasi dengan metode sapuan. Enam belas spesies dari 6 genera udang ditemukan di Laut Jawa dengan lima spesies dominan adalah Metapenaeopsis palmensis (53,33\%), Metapenaeus ensis (14,98\%), Trachypenaeus malaiana (12,89\%), Penaeus semisulcatus $(6,16 \%)$ dan Metapenaeopsis stridulans (5,21\%). Rerata panjang karapas udang yang dominan yaitu udang krosok (M. palmensis) adalah $14 \mathrm{~mm}$ untuk udang jantan dan $16 \mathrm{~mm}$ untuk udang betina. Secara horisontal, penyebaran udang tertinggi ditemukan di perairan selatan Kalimantan Tengah, perairan utara Sumenep, perairan sekitar Pulau Bawean dan utara Tegal. Berdasarkan kedalaman, penyebaran udang tertinggi ditemukan pada kedalaman 40-50 m. Rerata kepadatan stok udang di Laut Jawa sebesar $21,34 \pm 16,81 \mathrm{~kg} / \mathrm{km}^{2}$ dan laju tangkap sebesar $1 \pm 0,5 \mathrm{~kg} / \mathrm{jam}$. Estimasi biomasa udang di Laut Jawa sebesar 9.938 ton.
\end{abstract}

Kata Kunci: Kepadatan stok; komposisi; Laut Jawa; sebaran; udang

\section{ABSTRACT}

Shrimp resources in Java Sea have been exploited for years and its activity affected the changes of shrimps stock abundance and aquatic ecology. Data and the latest information about catch rate, composition, distribution, density and biomass of shrimps were required as a basis of sustainable management in Java Sea. The aim of this research were to determine catch rate, composition, distribution, density and biomass of shrimps in Java Sea. The Research was conducted from October until November 2015 using Research vessel Madidihang 02 in Java Sea. Swept Area Method was used for stock density estimation. The aims of this research were to determine catch rate, composition, distribution and stock density of shrimps in Java Sea. Sixteen species from 6 genera of shrimps were found in Java Sea. The Dominant species of shrimps in Java sea were Metapenaeopsis palmensis (53,33\%), Metapenaeus ensis (14,98\%), Trachypenaeus malaiana (12,89\%), Penaeus semisulcatus $(6,16 \%)$ and Metapenaeopsis stridulans (5,21\%). The most dominant shrimps caught were velvet shrimps (M. palmensis) of the average size of $14 \mathrm{~mm}$ carapace length for males and $16 \mathrm{~mm}$ carapace length for females. The highest stock density of Penaeid shrimps were found in the southern waters of Kalimantan Central, northern waters of Sumenep and the waters around Bawean island and Northern waters of Tegal. The highest stock density were found in depth of 40-50 m. The average density of Penaeid shrimps in the Java sea was $21.34 \pm 16.81 \mathrm{~kg} / \mathrm{km}^{2}$ and the catch rate was $1 \pm 0,5 \mathrm{~kg} / \mathrm{hour}$. Biomass estimation of shrimps in Java Sea were 9.938 ton.

Keywords: Stock density; composition; Java Sea, distribution; shrimps

Korespondensi penulis:

e-mail: tirtadanu91@gmail.com 


\section{PENDAHULUAN}

Udang merupakan komoditas penting karena memiliki nilai ekonomi dan berperan secara ekologi sebagai mangsa beberapa jenis ikan demersal. Beberapa spesies udang diantaranya Metapenaeus spp., Penaeus merguiensis dan Penaeus semisulcatus memiliki nilai ekonomi tinggi. Selain berperan secara ekonomi, udang juga berperan penting secara ekologi. Udang krosok (Metapenaeopsis spp.) berperan sebagai mangsa bagi ikan demersal (Linke et al., 2001 ; Raymundo-Huzair et al., 2005). Kelompok Crustacea yang berukuran relatif kecil, tergolong dalam kategori trofik paling penting dan sebagai mangsa yang dibutuhkan bagi berbagai jenis dan ukuran beberapa ikan demersal (Pessanha \& Araujo, 2012).

Sebagian besar udang menyebar di daerah tropis dan subtropis (King, 1995). Salah satu habitat penyebaran udang berada di Laut Jawa. Laut Jawa merupakan perairan yang relatif dangkal dengan kedalaman perairan sebagian besar kurang dari 200 $\mathrm{m}$ dengan substrat lumpur dan lumpur berpasir. Kondisi perairan yang dangkal dengan substrat berlumpur serta keberadaan stok udang di Laut Jawa menyebabkan Laut Jawa menjadi salah satu daerah

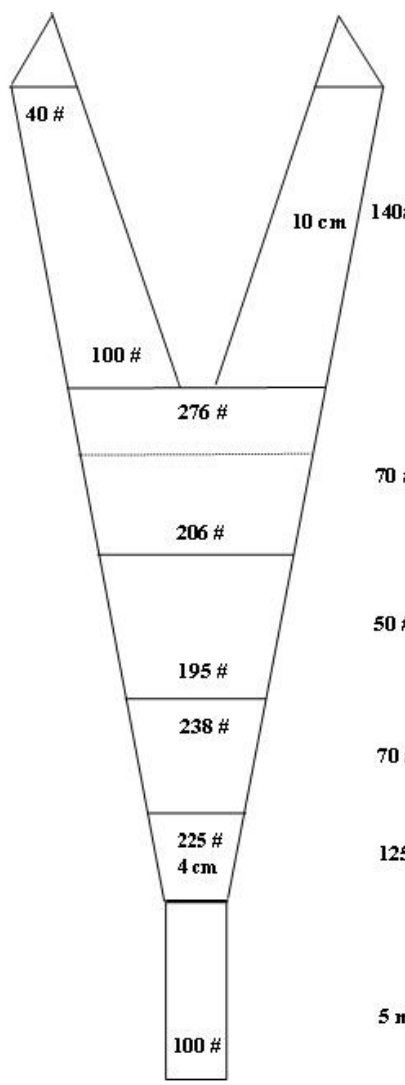

yang intensif bagi penangkapan udang. Penangkapan udang di Laut Jawa telah dilakukan sejak lama. Penelitian terkait kelimpahan stok ikan di Laut Jawa pernah dilakukan pada tahun 1974 (Losse \& Dwiponggo, 1977).

Dalam rangka penyusunan strategi pemanfaatan sumberdaya udang di Laut Jawa yang berkelanjutan maka diperlukan pengelolaan yang rasional. Sebagai dasar pengelolaan tersebut diperlukan informasi berkaitan dengan komposisi, sebaran dan kepadatannya. Tulisan ini bertujuan untuk mengkaji komposisi, sebaran dan kepadatan stok udang di Laut Jawa.

\section{METODE PENELITIAN}

Penelitian dilaksanakan pada Oktober 2015 sampai November 2015 dengan menggunakan Kapal Riset Madidihang 02 dengan ukuran kapal 163 GT dengan panjang (LOA) $35 \mathrm{~m}$, lebar 6,3 m dan tinggi $3 \mathrm{~m}$. Alat tangkap yang digunakan adalah alat tangkap trawl dengan mata jaring sebesar $4 \mathrm{~cm}$ di bagian kantong. Panjang tali ris atas $36 \mathrm{~m}$ dan tali ris bawah $41 \mathrm{~m}$. Jumlah pelampung yang digunakan sebanyak 15 buah dengan pemberat berupa rantai besi seberat $150 \mathrm{~kg}$ (Gambar 1).

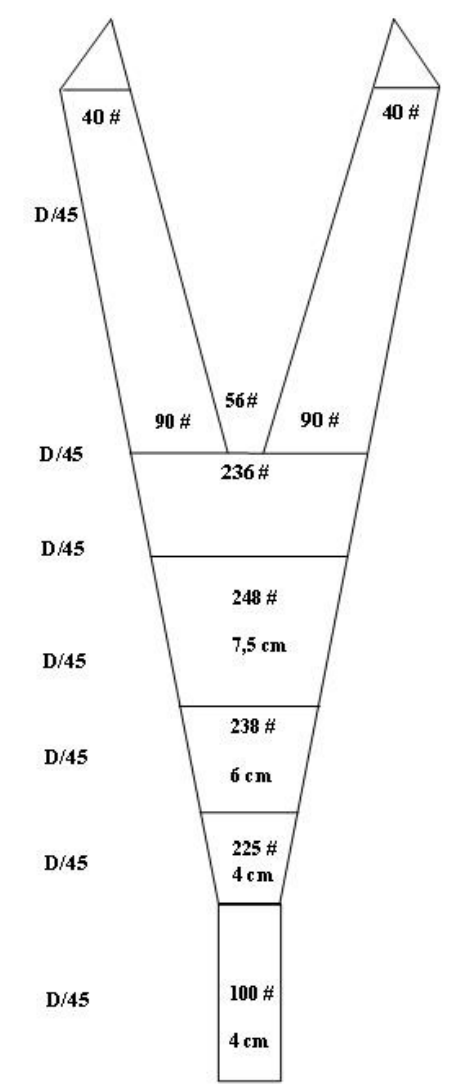

Gambar 1. Desain udang trawl yang dioperasikan pada Kapal Madidihang 02.

Figure 1. Shrimp trawl design operated by vessel Madidihang 02. 
Lokasi penelitian adalah sepanjang Laut Jawa pada koordinat $107^{\circ} \mathrm{BT}-114^{\circ} \mathrm{BT}$ dan $3^{\circ} \mathrm{LS}-6^{\circ} \mathrm{LS}$. Pengambilan sampel dilakukan pada tiap lokasi dari
39 stasiun penangkapan pada kisaran kedalaman perairan antara 10 hingga $80 \mathrm{~m}$ (Gambar 2).

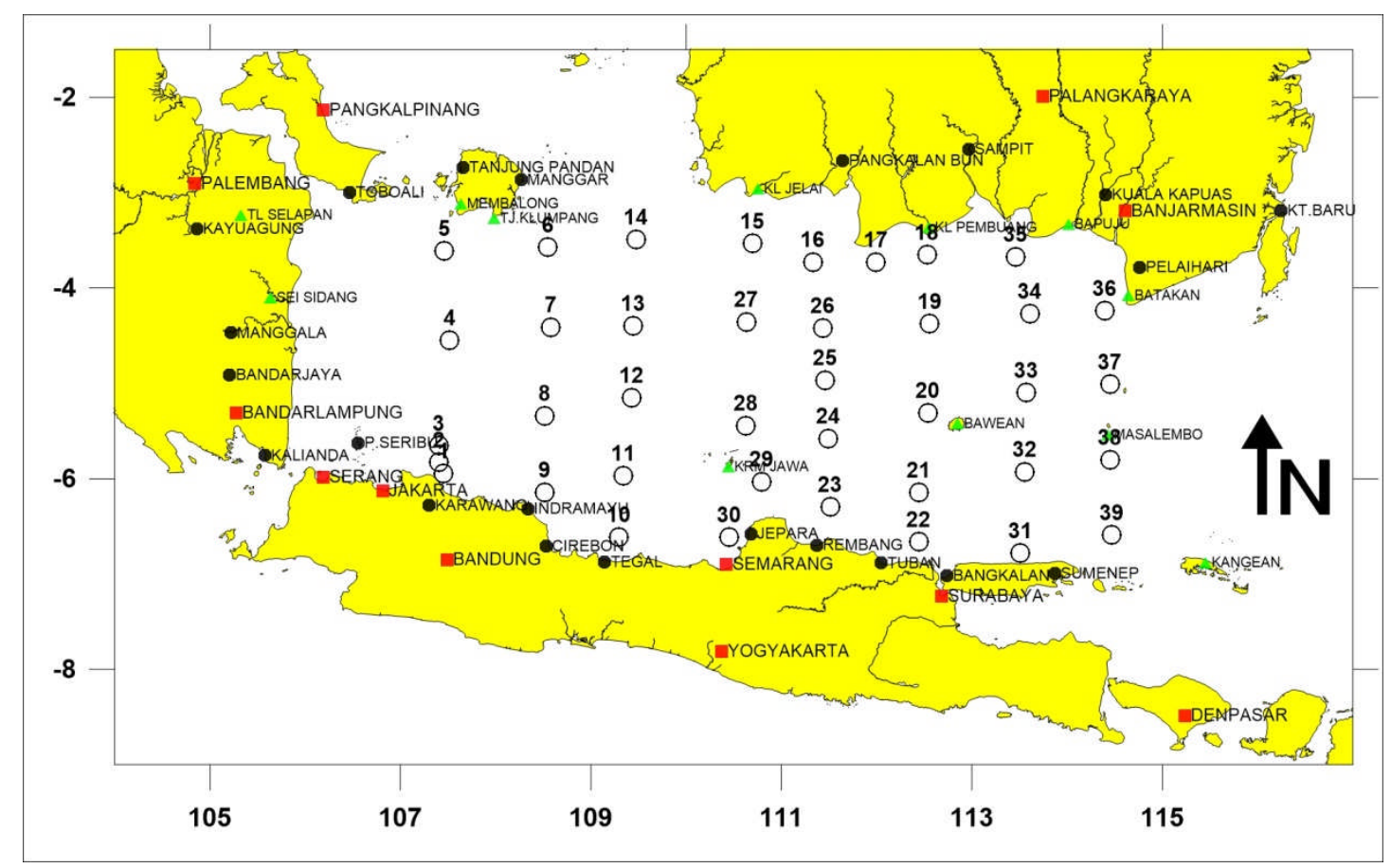

Gambar 2. Peta pengoperasian jaring trawl di Laut Jawa.

Figure 2. Map of trawl net operated in Java Sea.

Penghitungan kepadatan stok udang menggunakan metode sapuan (Swept area) dengan luas area merupakan perkalian antara panjang sapuan dan lebar mulut jaring. Penghitungan indeks kepadatan stok yaitu (Sparre and Venema, 1992) :

$$
\begin{aligned}
a & =V x t \times h r \times X 2 \times 1,852 \times 0,001 \\
D & =\left(\frac{1}{a}\right) \times\left(\frac{c}{f}\right)
\end{aligned}
$$

dimana:

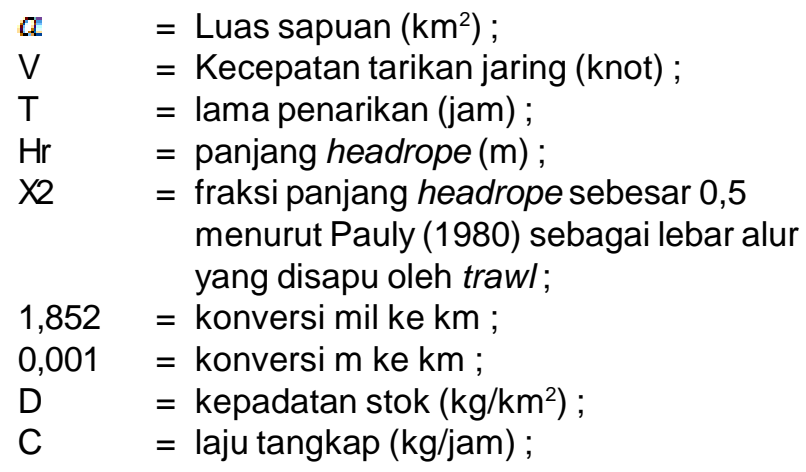

$\mathrm{F}$ = escapement factor sebagai dugaan proporsi ikan pada alur sapuan dan tertangkap jaring sebesar 0,5 (Saeger et al., 1976).

Sebaran stok udang dilakukan dengan memplotkan kepadatan stok $\left(\mathrm{kg} / \mathrm{km}^{2}\right)$ pada peta. Kepadatan stok $\left(\mathrm{kg} / \mathrm{km}^{2}\right)$ dan laju tangkap (kg/jam) dianalisis per strata kedalaman perairan diantaranya kedalaman 10-20 m, 20-30 m, 30-40 m, 40-50 m, 50$60 \mathrm{~m}$ dan $>60 \mathrm{~m}$. Jenis udang diidentifikasi berdasarkan FAO (1998), komposisi jenis udang dianalisis berdasarkan presentase spesies (\%) per kedalaman.

Analisis frekuensi panjang meliputi grafik frekuensi panjang jantan dan betina yang disajikan dalam grafik batang. Panjang udang yang diukur adalah panjang karapas (Carapace Length). Nisbah kelamin dihitung dengan cara membandingkan jumlah udang jantan dan betina. Penentuan seimbang tidaknya nisbah kelamin jantan dan betina dilakukan uji Chi-square (Walpole, 1993). 


\section{HASIL DAN BAHASAN}

Hasil

\section{Sebaran Laju tangkap}

Rata-rata laju tangkap udang di Laut Jawa sebesar $1 \pm 0,5 \mathrm{~kg} / \mathrm{jam}$ dan rata-rata laju tangkap ikan sebesar
$58 \pm 12 \mathrm{~kg} / \mathrm{jam}$. Rata-rata laju tangkap udang tertinggi $(2,09 \mathrm{~kg} / \mathrm{jam})$ berada pada kedalaman antara 40-50 $\mathrm{m}$ dan rata-rata laju tangkap ikan tertinggi $(68,77 \mathrm{~kg} /$ jam) berada pada kedalaman antara 30-40 m. (Tabel 1). Proporsi udang terhadap total hasil tangkapan sebesar $1,69 \%$.

Tabel 1. Laju tangkap udang, ikan dan total di Laut Jawa

Table 1. Catch rate of shrimp, fish and total catch in Java Sea

\begin{tabular}{|c|c|c|c|c|c|c|c|}
\hline \multirow{2}{*}{$\begin{array}{l}\text { Kedalaman } \\
\text { Depth range }\end{array}$} & \multirow{2}{*}{$\begin{array}{c}\text { No. Station } \\
\text { Station Number }\end{array}$} & \multicolumn{2}{|c|}{$\begin{array}{c}\text { Rerata Laju } \\
\text { Tangkap Udang } \\
\text { Catch rate average } \\
\text { of Shrimps } \\
\end{array}$} & \multicolumn{2}{|c|}{$\begin{array}{c}\text { Rerata Laju Tangkap } \\
\text { Ikan } \\
\begin{array}{c}\text { Catch rate average of } \\
\text { Fishes }\end{array} \\
\end{array}$} & \multicolumn{2}{|c|}{$\begin{array}{c}\text { Rerata Laju Tangkap } \\
\text { Total } \\
\text { Average Catch rate }\end{array}$} \\
\hline & & $\begin{array}{l}\text { W (kg) } \\
\text { W (kg) }\end{array}$ & $\begin{array}{l}\mathrm{N} \text { (ekor) } \\
\mathrm{N} \text { (ind) }\end{array}$ & $\begin{array}{l}\text { W (kg) } \\
\text { W (kg) }\end{array}$ & $\begin{array}{l}\mathrm{N} \text { (ekor) } \\
\mathrm{N} \text { (ind) }\end{array}$ & $\begin{array}{l}\text { W (kg) } \\
\text { W (kg) }\end{array}$ & $\begin{array}{c}\mathbf{N} \text { (ekor) } \\
\mathrm{N} \text { (ind) }\end{array}$ \\
\hline $10-20$ & 35; 15; 15 & 0.68 & 92 & 63.64 & 2863 & 64.31 & 2956 \\
\hline $20-30$ & 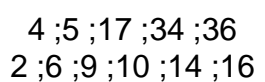 & 0.53 & 15 & 51.93 & 814 & 52.46 & 830 \\
\hline $30-40$ & 23; 19; 13; 8; ; ; 3 ; 3 & 1.34 & 221 & 68.77 & 1796 & 70.11 & 2017 \\
\hline $40-50$ & 29; 26; 22; 27 ; $; 2$; 11 & 2.09 & 332 & 53.60 & 1163 & 55.69 & 1495 \\
\hline $50-60$ & 28 25; 25; 33; 21 ; 21 ; 20 & 0.77 & 146 & 65.97 & 1332 & 66.74 & 1478 \\
\hline$>60$ & ;32;39 & 0.32 & 78 & 64.92 & 2070 & 65.24 & 2148 \\
\hline Total & 39 & $1 \pm 0.5$ & $164 \pm 95$ & $58 \pm 12$ & $1550 \pm 479$ & $59.17 \pm 12.5$ & $1701 \pm 499$ \\
\hline
\end{tabular}

\section{Komposisi Jenis Udang}

Berdasarkan hasil penelitian, ditemukan sebanyak 16 spesies dari 6 genera udang Penaeidae di Laut Jawa diantaranya enam spesies dari genera Penaeus, empat spesies dari genera Metapenaeus, tiga spesies dari genera Metapenaeopsis satu spesies dari genera Trachypenaeus, satu spesies dari genera Parapenaeopsis dan satu spesies dari genera Parapenaeus. (Tabel 2).

Tabel 2. Jenis udang di Laut Jawa

Tabel 2. Species of shrimps in Java Sea

\begin{tabular}{|c|c|c|c|c|}
\hline $\begin{array}{l}\text { Famili } \\
\text { Family }\end{array}$ & $\begin{array}{l}\text { Genera } \\
\text { Genus }\end{array}$ & $\begin{array}{l}\text { Spesies } \\
\text { Species }\end{array}$ & $\begin{array}{c}\text { Total N (ekor) } \\
\text { Total N (ind) }\end{array}$ & $\begin{array}{l}\text { Total W (kg) } \\
\text { Total W( } \mathbf{k g})\end{array}$ \\
\hline \multirow{16}{*}{ Penaeidae } & Penaeus & Penaeus semisulcatus & 66 & 2.23 \\
\hline & & Penaeus merguensis & 36 & 1.40 \\
\hline & & Penaeus monodon & 1 & 0.13 \\
\hline & & Penaeus japonicus & 1 & 0.05 \\
\hline & & Penaeus latisulcatus & 1 & 0.02 \\
\hline & & Penaeus longistylus & 1 & 0.01 \\
\hline & Metapenaeus & Metapenaeus ensis & 267 & 5.43 \\
\hline & & Metapenaeus intermedius & 20 & 0.51 \\
\hline & & Metapenaeus affinis & 2 & 0.05 \\
\hline & & Metapenaeus lysianassa & 5 & 0.01 \\
\hline & Metapenaeopsis & Metapenaeopsis palmensis & 4066 & 19.34 \\
\hline & & Metapenaeopsis stridulans & 418 & 1.89 \\
\hline & & Metapenaeopsis lamellata & 4 & 0.03 \\
\hline & Trachypenaeus & Trachypenaeus malaiana & 882 & 4.68 \\
\hline & Parapenaeus & Parapenaeus longipes & 134 & 0.42 \\
\hline & Parapenaeopsis & Parapenaeopsis hardwickii & 7 & 0.08 \\
\hline \multicolumn{3}{|c|}{ Total } & 5911 & 36.26 \\
\hline
\end{tabular}


Komposisi jenis udang di Laut Jawa didominasi oleh Metapenaeopsis palmensis (53,33\%), Metapenaeus ensis (14,98\%), Trachypenaeus malaiana (12,89\%), Penaeus semisulcatus $(6,16 \%)$ dan Metapenaeopsis stridulans (5,21\%). Tiga spesies udang ekonomis penting dengan persentase tinggi diantaranya udang dogol (Metapenaeus ensis), udang tiger (Penaeus semisulcatus) dan udang jerbung (Penaeus merguiensis) (Tabel 3).
Komposisi jenis udang di Laut Jawa mengalami perbedaan pada beberapa strata kedalaman. Metapenaeus ensis dominan ditemukan pada strata kedalaman yang dangkal yaitu $10-30 \mathrm{~m}$, sedangkan $30 \mathrm{~m}$ hingga lebih dari $60 \mathrm{~m}$ didominasi oleh Metapenaeopsis palmensis. Metapenaeopsis palmensis menyebar pada setiap strata kedalaman di Laut Jawa. Genera Parapenaeus yaitu Parapenaeus longipes ditemukan pada perairan yang lebih dalam yaitu lebih dari $50 \mathrm{~m}$ (Tabel 3).

Tabel 3. Komposisi jenis udang di Laut Jawa

Table 3. Composition of shrimps in Java Sea

\begin{tabular}{|c|c|c|c|c|c|c|c|c|}
\hline \multirow{2}{*}{$\begin{array}{l}\text { Spesies } \\
\text { Species }\end{array}$} & \multicolumn{6}{|c|}{$\begin{array}{c}\text { Total W }(\mathrm{kg}) \text { berdasarkan kedalaman } \\
\text { Total W }(\mathrm{kg}) \text { by Depths }\end{array}$} & \multirow{2}{*}{$\begin{array}{c}\text { Total } \\
W \\
(\mathrm{~kg}) \\
\\
\\
\text { Total } \\
W \\
(\mathrm{~kg}) \\
\end{array}$} & \multirow{2}{*}{$\begin{array}{l}\text { Persentase } \\
\text { (\%) } \\
\text { Percentage } \\
\text { (\%) }\end{array}$} \\
\hline & $\begin{array}{c}10-20 \\
\mathrm{~m}\end{array}$ & $\begin{array}{c}20-30 \\
\mathrm{~m}\end{array}$ & $\begin{array}{c}30-40 \\
\mathrm{~m}\end{array}$ & $\begin{array}{c}40-50 \\
\mathrm{~m}\end{array}$ & $50-60 \mathrm{~m}$ & $>60 \mathrm{~m}$ & & \\
\hline Metapenaeopsis palmensis & 0.57 & 0.10 & 6.55 & 8.76 & 2.38 & 0.98 & 19.34 & 53.33 \\
\hline Metapenaeus ensis & 0.58 & 1.50 & 1.14 & 1.41 & 0.80 & & 5.43 & 14.98 \\
\hline Trachypenaeus malaiana & 0.16 & & 0.33 & 2.11 & 1.55 & 0.53 & 4.68 & 12.89 \\
\hline Penaeus semisulcatus & 0.13 & & 0.78 & 1.02 & 0.26 & 0.04 & 2.23 & 6.16 \\
\hline Metapenaeopsis stridulans & & & 0.79 & 0.82 & 0.19 & 0.09 & 1.89 & 5.21 \\
\hline Penaeus merguensis & 0.32 & & 1.06 & & 0.02 & & 1.40 & 3.86 \\
\hline Metapenaeus intermedius & & & 0.05 & 0.39 & 0.07 & & 0.51 & 1.39 \\
\hline Parapenaeus longipes & & & & 0.06 & 0.11 & 0.25 & 0.42 & 1.17 \\
\hline Penaeus monodon & 0.13 & & & & & & 0.13 & 0.36 \\
\hline Parapenaeopsis hardwickii & 0.08 & & & & & & 0.08 & 0.21 \\
\hline Metapenaeus affinis & 0.05 & & & & & & 0.05 & 0.14 \\
\hline Penaeus japonicus & & & & 0.05 & & & 0.05 & 0.14 \\
\hline Metapenaeopsis lamellata & & & 0.03 & & & & 0.03 & 0.07 \\
\hline Penaeus latisulcatus & & & & & 0.02 & & 0.02 & 0.06 \\
\hline Metapenaeus Iysianassa & 0.01 & & & & & & 0.01 & 0.03 \\
\hline Penaeus longistylus & & & & & & 0.01 & 0.01 & 0.03 \\
\hline Total & 2.03 & 1.60 & 10.73 & 14.62 & 5.39 & 1.90 & 36.26 & 100 \\
\hline
\end{tabular}

Rata-rata panjang karapas udang yang dominan yaitu udang krosok (M. palmensis) adalah $13,85 \pm 0,19$ mm pada udang jantan dan 16,62 $\pm 0,22 \mathrm{~mm}$ pada udang betina. Kisaran panjang karapas udang krosok (Metapenaeopsis palmensis) di Laut Jawa 8-28 mm. Ukuran udang krosok yang besar lebih banyak ditemukan pada kedalaman $<30 \mathrm{~m}$ dengan modus ukuran panjang karapas sebesar $18 \mathrm{~mm}$, dibandingkan dengan udang krosok yang tertangkap pada kedalaman 30-70 m dengan modus panjang karapas sebesar $14 \mathrm{~mm}$ (Gambar 3).

Total rasio kelamin udang krosok menunjukkan kondisi tidak seimbang dengan jumlah udang krosok betina lebih besar dibandingkan udang jantan. Hal tersebut menunjukkan bahwa udang betina yang tertangkap lebih dominan. Rasio kelamin per kedalaman menunjukkan kondisi seimbang pada kedalaman 20-30 m dan 50-60 m (Tabel 4). 


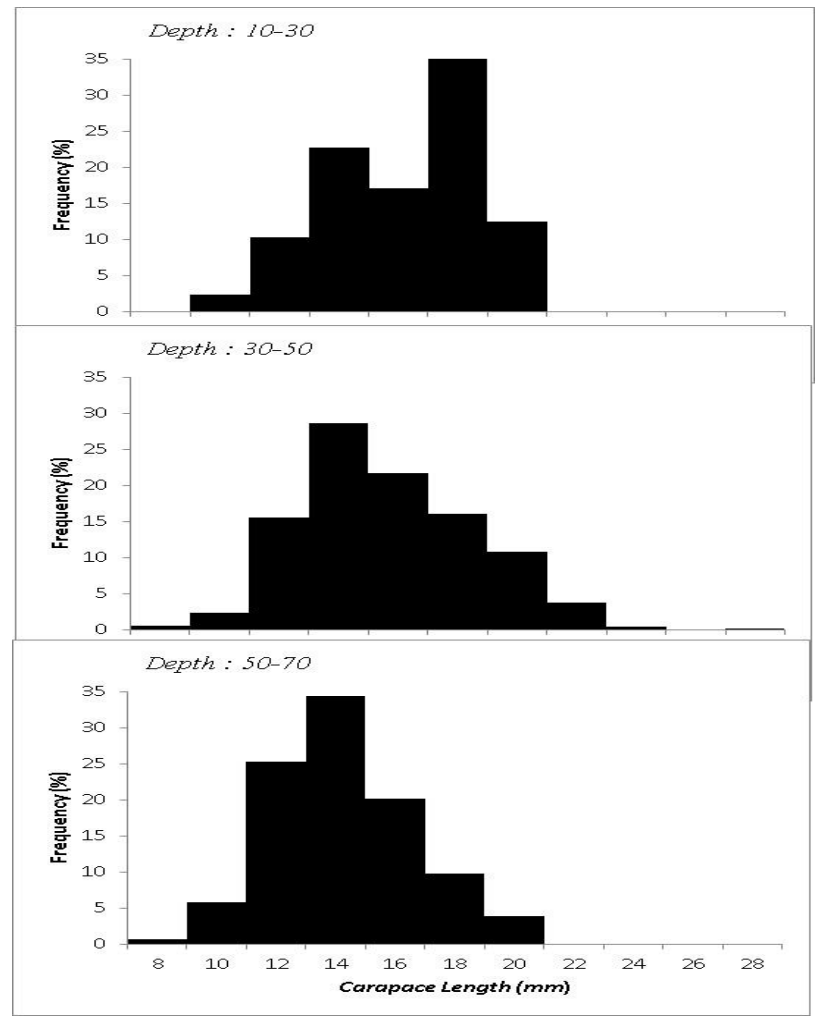

Gambar 3. Sebaran panjang karapas udang krosok (Metapenaeopsis palmensis) berdasarkan stratifikasi di Laut Jawa.

Figure 3. Carapace length frequencies of Velvet Shrimps (Metapenaeopsis palmensis) by depths in Java Sea.

Tabel 4. Rasio kelamin dan modus panjang karapas udang krosok di Laut Jawa.

Table 4. Sex ratio and carapace length mode of velvet shrimps in Java Sea.

\begin{tabular}{|c|c|c|c|c|c|c|}
\hline \multirow{2}{*}{ Kedalaman } & \multicolumn{4}{|c|}{ Jumlah } & \multirow{2}{*}{ Hasil } & \multirow{2}{*}{$\begin{array}{c}\text { Modus Ukuran } \\
\text { (mm) }\end{array}$} \\
\hline & Jantan & Betina & M:F Ratio & $\mathrm{X}^{2}$ & & \\
\hline $10-20$ & 23 & 58 & $1: 2.52$ & 15.12 & tidak seimbang & 18 \\
\hline $20-30$ & 3 & 4 & $1: 1.33$ & 0.14 & seimbang & 18 \\
\hline $30-40$ & 60 & 101 & $1: 1.68$ & 10.44 & tidak seimbang & 14 \\
\hline $40-50$ & 141 & 252 & $1: 1.78$ & 31.35 & tidak seimbang & 14 \\
\hline $50-60$ & 87 & 110 & $1: 1.26$ & 2.68 & seimbang & 14 \\
\hline$>60$ & 29 & 82 & $1: 2.82$ & 25.31 & tidak seimbang & 14 \\
\hline Total & 343 & 607 & $1: 1.77$ & 73.36 & tidak seimbang & Modus $=14 \mathrm{~mm}$ \\
\hline
\end{tabular}

\section{Sebaran, Kepadatan Stok dan Biomasa Udang}

Total sampel udang yang tertangkap sebanyak 5911 ekor udang dengan berat sebesar $36,26 \mathrm{~kg}$. Daerah dengan kepadatan stok yang tinggi berada pada stasiun 16 yang berada di perairan pantai selatan Kalimantan ; stasiun 31 di pantai utara Sumenep, stasiun 19 di perairan selatan Kalimantan, stasiun 33 di sekitar perairan Pulau Bawean dan stasiun 13 di perairan utara Tegal (Gambar 4). 


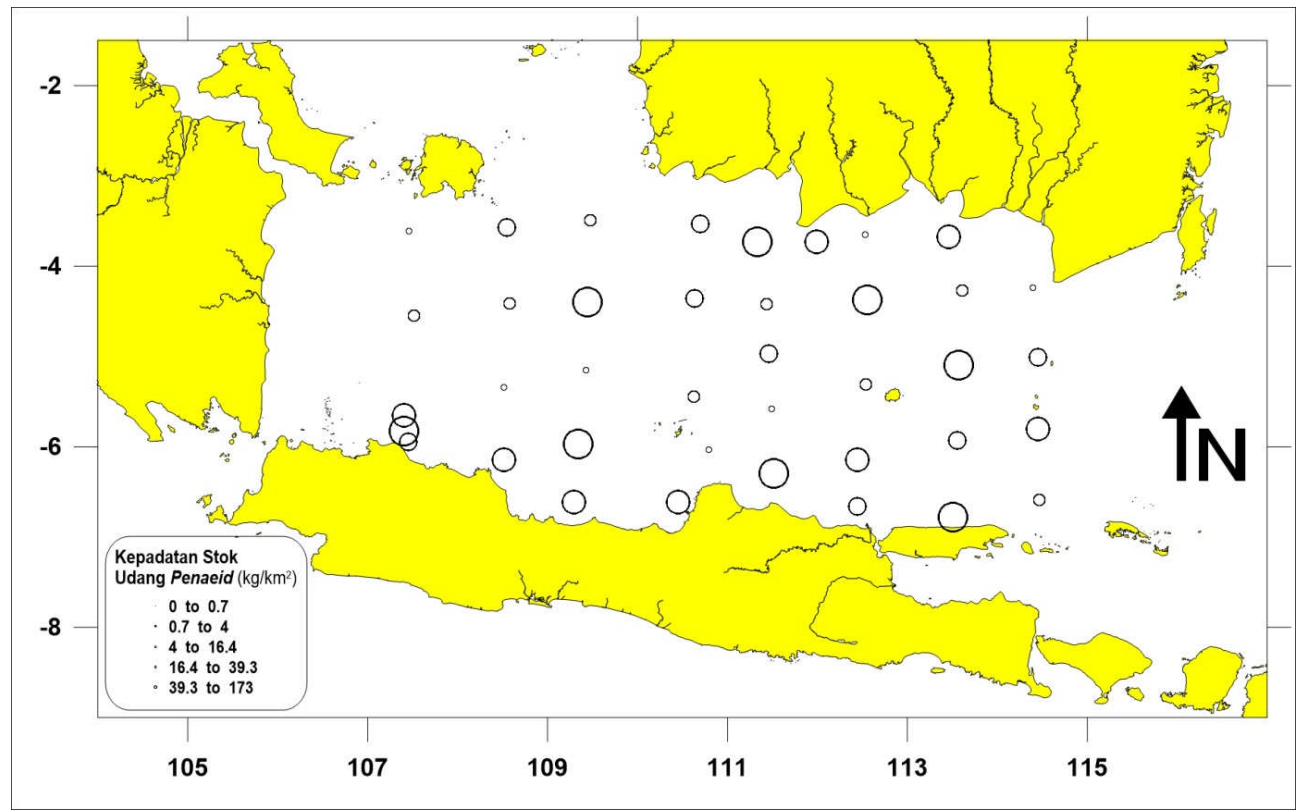

Gambar 4. Peta sebaran kepadatan udang di Laut Jawa.

Figure 4. Distribution of shrimps stock density in Java Sea.

Rata-Rata kepadatan stok udang di Laut Jawa sebesar $21.34 \pm 16.81 \mathrm{~kg} / \mathrm{km}^{2}$ dengan laju tangkap sebesar $0.85 \pm 0.66 \mathrm{~kg} / \mathrm{jam}$. Kepadatan stok udang tertinggi berada pada kedalaman $40-50 \mathrm{~m}$ sedangkan kepadatan terendah berada pada kedalaman $>60 \mathrm{~m}$ (Tabel 5). Luas area Laut Jawa menurut Losse (1981) sebesar $465.680 \mathrm{~km}^{2}$ sehingga estimasi biomassa udang di Laut Jawa sebesar 9.938 ton.

\begin{tabular}{|c|c|c|}
\hline $\begin{array}{c}\text { Kedalaman } \\
\text { Depth } \\
(\mathrm{m}) \\
(\mathrm{m})\end{array}$ & $\begin{array}{c}\text { Laju Tangkap } \\
\text { Catch Rate } \\
\text { (kg/jam) } \\
\text { (kg/hours) }\end{array}$ & $\begin{array}{c}\text { Kepadatan Stok } \\
\text { Stock Density } \\
\left(\mathrm{kg} / \mathrm{km}^{2}\right) \\
\left(\mathrm{kg} / \mathrm{km}^{2}\right) \\
\end{array}$ \\
\hline $10-20$ & 0,68 & 12,29 \\
\hline $20-30$ & 0,53 & 7,68 \\
\hline $30-40$ & 1,34 & 35,99 \\
\hline $40-50$ & 2,09 & 45,80 \\
\hline $50-60$ & 0,77 & 19,01 \\
\hline$>60$ & 0,32 & 7,29 \\
\hline $\begin{array}{l}\text { Rata-Rata } \\
\text { (Average) }\end{array}$ & $1 \pm 0,5$ & $21,34 \pm 16,81$ \\
\hline
\end{tabular}

\section{Bahasan}

Di Laut Jawa ditemukan sebanyak 16 spesies udang dan yang paling dominan adalah udang krosok atau velvet shrimp (Metapenaeopsis palmensis). Udang krosok jenis $M$. palmensis belum pernah terlaporkan sebagai spesies yang paling dominan di Laut Jawa. Kondisi tersebut menunjukkan telah terjadi perubahan struktur komposisi udang di Laut Jawa.
Perubahan komposisi udang di Laut Jawa disebabkan oleh perubahan ekosistem pada perairan. Penurunan beberapa jenis udang dapat menyebabkan peningkatan frekuensi jenis udang lainnya akibat perubahan pada ekosistem (Duffy et al., 2013 ; Monk et al., 2015). Penurunan beberapa jenis udang akibat perubahan ekosistem diduga menjadi salah satu penyebab dominannya $M$. palmensis yang sebelumnya belum pernah terlaporkan di Laut Jawa. 
Perubahan komposisi di Laut Jawa terlaporkan terjadi di tahun 1979 dan 1980 dimana di tahun 1979, ikan Ariidae mendominasi hasil tangkapan sedangkan pada tahun 1980, ikan yang mendominasi adalah Lutjanidae (Suhendarata \& Badrudin, 1990). Perubahan komposisi dari jenis ikan dapat berpengaruh terhadap komposisi udang terkait dengan rantai makanan. Kondisi tersebut terjadi di Laut Atlantik dimana populasi udang sangat dipengaruhi oleh kepadatan predator. Peningkatan populasi ikan Cod sebagai predator menyebabkan penurunan populasi udang (Worm \& Myers, 2003). Saat ini, tingkat pemanfaatan sumberdaya udang di Laut Jawa telah overfishing dan banyak perikanan pukat cincin beralih ke perikanan cantrang (Wiadnyana et al., 2010 ; Atmaja \& Nugroho, 2010). Kondisi tersebut diduga menjadi salah satu penyebab perubahan kepadatan dan komposisi udang di Laut Jawa. Menurut Chen (2014), Udang jenis M. palmensis mampu melakukan pemulihan populasi dengan cepat pada perairan yang terganggu karena berumur pendek dan frekuensi pemijahan yang tinggi. Kondisi tersebut menyebabkan populasinya di Laut Jawa lebih dominan dibandingkan jenis udang lainnya.

Ukuran udang krosok pada perairan dangkal $(<30$ $\mathrm{m}$ ) di Laut Jawa lebih besar dibandingkan di perairan yang lebih dalam (>30 m). Hal tersebut disebabkan karena perbedaan penyebaran udang krosok juvenil dan dewasa. Nisbah kelamin udang krosok menunjukkan kondisi tidak seimbang dengan perbandingan $1: 1,77$, betina lebih dominan dibandingkan jantan. Kondisi serupa pada spesies Metapenaeopsis stridulans di perairan Chennai dengan perbandingan 1:1,2 (Pillai et al., 2012). Berbeda dengan di selat Kii, Jepang, nisbah kelamin M. palmensis menunjukkan kondisi seimbang (Hayashi dan Sakamoto, 1978). Menurut Wenner (1972), kondisi tidak seimbang antara jantan dan betina pada Crustacea dapat terjadi karena berbagai faktor diantaranya perbedaan laju pertumbuhan, migrasi, sex reversal dan perbedaan aktivitas makan.

Selain M. palmensis, spesies komersil yang dominan ditemukan di Laut Jawa diantaranya udang dogol (Metapenaeus ensis), udang tiger (Penaeus semisulcatus) dan udang jerbung (Penaeus merguiensis). Hal tersebut berkaitan dengan substrat berlumpur di Laut Jawa yang merupakan habitat yang sesuai bagi pertumbuhan beberapa spesies udang dominan tersebut (Somers et al., 1987). P. monodon ditemukan dengan jumlah yang lebih kecil dibandingkan $P$. semisulcatus, hal ini disebabkan kondisi substrat yang tidak sesuai untuk $P$. monodon yang hidup pada substrat yang berpasir (Mosha \& Gallardo, 2013).
Udang menyebar hampir di seluruh perairan Laut Jawa. Secara horisontal, kepadatan stok udang yang tinggi diantaranya di perairan selatan Kalimantan Tengah, perairan utara Sumenep, perairan sekitar Pulau Bawean dan utara Tegal. Kepadatan stok yang tinggi di selatan Kalimantan serupa dengan penelitian pada tahun 1977 di Laut Jawa (Losse \& Dwiponggo, 1977). Tingginya kepadatan stok udang di daerah tersebut diduga disebabkan substrat lumpur dengan kesuburan yang baik sehingga merupakan habitat yang cocok bagi pertumbuhan udang (Gribble et al., 2007). Secara vertikal, kepadatan stok udang tertinggi di Laut Jawa berada pada kisaran kedalaman 40 hingga $50 \mathrm{~m}$. Kepadatan stok yang tinggi diduga disebabkan karena sebagian besar nelayan melakukan penangkapan intensif pada kedalaman kurang dari $20 \mathrm{~m}$. Pada kedalaman yang lebih dalam udang belum tereksploitasi secara penuh sehingga populasi udang dapat tumbuh dengan baik.

\section{KESIMPULAN}

Udang yang ditemukan di Laut Jawa terdiri dari 6 genera meliputi 16 spesies dan spesies yang paling dominan adalah udang krosok (Metapenaeopsis palmensis). Secara horisontal, penyebaran udang yang tinggi ditemukan di perairan selatan Kalimantan Tengah, perairan utara Sumenep, perairan sekitar Pulau Bawean dan utara Tegal. Berdasarkan strata kedalaman, penyebaran udang tertinggi ditemukan pada kedalaman 40-50 m. Rata-rata kepadatan stok udang di Laut Jawa sebesar $21.34 \pm 16.81 \mathrm{~kg} / \mathrm{km}^{2}$ dan laju tangkap sebesar $1 \pm 0,5 \mathrm{~kg} / \mathrm{jam}$. Estimasi biomasa udang di Laut Jawa sebesar 9.938 ton.

\section{PERSANTUNAN}

Tulisan ini merupakan bagian dari kegiatan penelitian "Karakteristik Biologi Perikanan, Potensi, Produksi dan Habitat Sumber Daya Ikan di perairan WPP 712" yang diselenggarakan oleh Balai Penelitian Perikanan Laut, Muara Baru, Jakarta. TA. 2015.

\section{DAFTAR PUSTAKA}

Atmaja, S.B., \& Nugroho, D. (2012). Distribusi Spasial Upaya Penangkapan Kapal Cantrang dan Permasalahannya di Laut Jawa. J. Lit. Perikan. Ind 18(4): 231-241.

Chen, H.S., Chen, C.Y., \& Chen, M. H. (2014). Life History tactics of southern velvet shrimp Metapenaeopsis palmensis (Crustacea, Decapoda) in the waters off southwestern Taiwan. Hydrobiologia. $15 \mathrm{p}$. 
Duffy, J.E., Macdonald, K.S., Hultgren, K.M., Chak, T.C.S., \& Rubenstein, D.R. (2013). Decline and Local Extinction of Carribbean Eusocial Shrimp. Plos One, 8(2).

FAO. (1998). The living marine resources of the Western Central Pacific Vol.2: Cephalopods, Crustaceans, Holothurians and Sharks. Rome: FAO Species Identification Guide for Fishery Purposes. $1396 \mathrm{p}$.

Gribble, N. A., Wassenberg, T. J., \& Burridge, C. (2007). Factors affecting the distribution of commercially exploited penaeid prawns (shrimp) (Decapod: Penaeidae) across the Northern Great Barrier Reef, Australia. Science Direct.Fisheries Research. 85: 175-185.

Hayashi, K.I., \& Sakamoto, T. (1978). Taxonomy and Biology of Metapenaeopsis palmensis (Haswell) (Crustacea, Decapoda, Penaeidae) Collected from the Kii Strait, Central Japan. Bulletin of the Japanese Society of Scientific Fisheries. 44(7): 709-714.

King, M. (1995). Fishery biology, assessment and management. United Kingdom: Fishing New Books. 341 p.

Linke, T. E., M. E. Platell., \& Potter, I. C. (2001). Factors influencing the partitioning of food resources among six fish species in a large embayment with juxtaposing bare sand and seagrass habitats. Journal of Experimental Marine Biology and Ecology, 266, 193-217.

Losse, G. F. (1981). Final report of the IndonesianGerman demersal fisheries project 1973-1979. Special Report. Contrib. of the Dem. Fish. Project. No.8. Marine Fisheries Research Report. RIMFGTZ. 45 pp.

Losse, G.F., \& Dwiponggo, A. (1977). Report on The Java Sea Southeast Monsoon Trawl Survey. Special Report. Marine Fisheries Research Report No.3, 123 p.

Monk, M.H., Powers, J.E., \& Brooks, E.N. (2015). Spatial patterns in species assemblages associated with the northwestern Gulf of Mexico shrimp trawl fishery. Marine Ecology Progress Series. 519: 1-12.
Mosha, E.J., \& Gallardo, W.G. (2013). Distribution and size composition of Penaeid Prawns, Penaeus monodon and Penaeus indicus in Saadan estuarine area, Tanzania. Ocean and Coastal Management Journal. 82: 51-63.

Pauly, D. (1980). A selection of simple methods for the assessment of tropical fish stocks. French: FAO Fish.Circ.54 p.

Pessanha, A. L. M., \& Araujo, F. G. (2012). Spatial and Size feeding niche partitioning of the rhomboid mojarra Diapterus rhombeus (Cuvier, 1829) in a tropicl Brazilian Bay. Marine Biology Research. 8: 273-283

Pillai, S. L., Kizhakudan, J. K., \& Thirumilu, P. (2012). Fishery and dynamics of the Fiddler Shrimp, Metapenaeopsis stridulans (Alcock, 1905) from Chennai Coast.J. Mar. Biol. Ass. India. 54(2): 9093.

Raymundo-Huizar, A., H. Perez-Espana, M. Mascaro., \& Chiappa-Carrara, X. (2005). Feeding habits of the dwarf weakfish (Cynoscion nannus) off the coasts of Jalisco and Colima, Mexico. Fisheries Bulletin. 103: 453-460.

Saeger, J., Martosubroto, P., \& Pauly, D. (1976). First report of the Indonesian-German demersal fisheries project (Result of a trawl survey in the Sunda Shelf area). Jakarta, Marine Fisheries Research Report (Special report). Contribution of the Demersal Fisheries Project no. 1, 46 pp.

Somers, I.F. (1987). Sediment type as a factor in the distribution of commercial prawns species in the western Gulf of Carpentaria, Australia. Cont. Shelf. Res. 7(10): 1139-1159.

Sparre, P., \& Venema, S.C. (1992). Introduction to Tropical Fish Stock Asseessment Part 1. Manual. FAO Fish. Tech. Pap. No. 1: 376 p.

Suhendarata, T., \& Badrudin, M. (1990). Sumberdaya Perikanan Demersal di Perairan Utara Rembang. Jurnal Pen. Perikanan Laut. 54: 1-7.

Walpole, R.V.E. (1993). Pengantar statistik. Terjemahan B. Sumantri (Edisi Tiga) Jakarta: PT. Gramedia. $321 \mathrm{p}$. 
Wenner, A. M. (1972). Sex ratio as a function of size in Marine Crustacean. American Nature. 106: 321351.

di Wilayah Pengelolaan Perikanan Laut Jawa. J. Lit. Perikan. Ind. 16(4): 259-331.

Worm \& Myers. (2003). Meta-Analysis of Cod-Shrimp

Wiadnyana, N. N., Badrudin., \& Aisyah. (2010). Tingkat Pemanfaatan Sumberdaya Ikan Demersal Interactions reveals top-down control in oceanic food webs. Ecology. 84(1): 162-173. 